\title{
STUDI LITERATUR POTENSI ANTIFUNGI DAUN KETEPENG CINA (Cassia alata L) TERHADAP JAMUR PATOGEN PADA MANUSIA
}

\author{
Rezki Amaliah ${ }^{1)}$, Mujahidah Basarang ${ }^{2)}$, Nurhidayat ${ }^{2)}$ \\ ${ }^{1)}$ Mahasiswa Prodi D4 Teknologi Laboratorium Medis Universitas Muhammadiyah Semarang \\ 2) Prodi D3 Teknologi Laboratorium Medis Politeknik Kesehatan Muhammadiyah Makassar \\ Alamat Korespondensi: @amaliahhrzkii08@gmail.com
}

\begin{abstract}
Abstrak
Jamur patogen ialah jamur penyebab infeksi penyakit pada manusia atau organisme lain. Jamur patogen ini biasanya menyebabkan penyakit yang disebut mikosis. Jamur penyebab mikosis diantaranya Malassezia furfur, Trichophyton sp, Candida albicans, Epidemaphyton dan Microsporum. Salah satu tanaman yang berpotensi sebagai pengobatan untuk infeksi jamur yaitu ketepeng cina (Cassia alata L) yang memiliki senyawa aktifflavonoid, saponin, tannin, dan alkaloid. Penelitian ini bertujuan mengetahui potensi antifungi daun ketepeng cina (Cassia alata L) terhadap jamur patogen pada manusia dengan jenis penelitian studi literatur. Referensi acuan penelitian studi literatur ini adalah 7 jurnal (jurnal sains dan kesehatan, Agromeducine, Internasional conference ministry of health polytechnic of kendari, El-Qudwah, Jurnal Photon, Pharmasipha, Jurnal penelitian farmasi Indonesia). Berdasarkan hasil penelitian studi literatur yang diperoleh dari penelitian sebelumnya didapatkan hasil daun ketepeng cina (Cassia alata L) mampu mampu menghambat pertumbuhan jamur Malassezia furfur, Trichophyton sp, Microsporum, Epidermaphyton dan Candida albicans karena memiliki senyawa aktif flavonoid, saponin, tannin, dan alkaloid berpotensi sebagai antifungi baik menggunakan teknik ekstraksi maupun perasan. Sehingga dapat disimpulkan daun ketepeng cina (Cassia alata L.) berpotensi sebagai antifungi terhadap beberapa jamur patogen pada manusia.
\end{abstract}

Kata Kunci: potensi antifungi, ketepeng cina, jamur patogen pada manusia

\section{PENDAHULUAN}

Indonesia merupakan salah satu negara yang beriklim tropis. kondisi ini merupakan kondisi lingkungan yang sesuai untuk pertumbuhan jamur karena memiliki suhu yang hangat dan kelembaban yang tinggi, hal ini menyebabkan penduduknya sangat rentan terkena infeksi jamur. Infeksi jamur biasanya disebabkan oleh jamur yang bersifat patogen.

Jamur patogen yang dapat menyebabkan infeksi antara lain Malassezia furfur, Trichophyton sp, Microsporum, Epidermophyton dan Candida albicans. Beberapa jamur patogen bersifat flora normal pada manusia tetapi dalam keadaan tertentu bisa menyebabkan infeksi. Diagnosis ditegakkan dengan pemeriksaan mikroskopik langsung dari kerokan yang terinfeksi dan ditambahkan dengan $\mathrm{KOH} 10-20 \%$ atau diwarnai dengan calcoflour white, serta pemeriksaan biakan
(Brooks et al, 2013).

Penyakit infeksi yang disebabkan oleh jamur sering terjadi dikalangan masyarakat sedangkan obat anti jamur lebih sedikit dibandingkan dengan anti bakteri, sehingga perlu dilakukan pengembangan obat anti jamur. Penggunaan tanaman obat tradisional sebagai pilihan pengobatan sehari-hari kembali meningkat, karena obat tradisional terbukti relatif aman asalkan cara penggunaan serta dosis yang benar, dan dengan indikasi yang tepat jarang sekali menimbulkan efek samping.

Salah satu tanaman yang mempunyai potensi untuk pengobatan infeksi jamur adalah ketepeng cina (Cassia alata L). Bagian yang sering digunakan sebagai obat ialah bagian daun. Daun ketepeng cina biasa digunakan masyarakat sebagai obat dengan cara menggosokkan pada kulit atau ditumbuk sampai lumat lalu diusapkan pada 
kulit yang terkena infeksi. Kandungan kimia daun ketepeng cina berfungsi sebagai antiinflamasi, antialergi, antimikroba, antioksidan, dan efektif untuk beberapa golongan jamur seperti alkaloid, saponin, tanin, antrakuinon, flavonoid. Pada tahun 1994, efek pengobatan ekstrak daun ketepeng cina (Cassia alata L) telah dilaporkan pertama kali untuk pengobatan pada jamur yang dapat menyebabkan pityriasis versicolor dan tidak memiliki efek samping (Edo et al, 2017).

Penelitian yang telah dilakukan oleh Gama et al (2011) menunjukkan efektifitas dari daun ketepeng cina dengan konsentrasi $50 \%$ sebanding dengan ketokenazol 2\%. Pada penelitian Purwani (2013) menunjukkan semakin tinggi konsentrasi ekstrak daun ketepeng cina semakin tinggi zona hambat dari pertumbuhan jamur Malassezia furfur.

Berdasarkan latar belakang di atas maka perlu dilakukan penelitian tentang potensi antifungi daun ketepeng cina
(Cassia alata L) terhadap Malassezia furfur.

\section{METODE PENELITIAN}

Jenis penelitian yang digunakan pada penelitian ini adalah studi literatur dengan cara melakukan pendekatan kajian kepustakaan yang relevan dengan judul penelitian dengan cara mengakses jurnal, artikel dan buku dengan kata kunci aktivitas antifungi, Cassia alata $L$, jamur patogen pada manusia. Dengan melakukan pencarian data primer, dilakukan menggunakan instrument online seperti Google atau Google scholar yang dipublikasikan 2010-2019 sebagai sumber informasi dan data peneliti dengan kata kunci "aktivitas antifungi, ketepeng cina (Cassia alata L), jamur patogen pada manusia". Kemudian hasil penelitian studi literature disajikan dalam bentuk tabel dengan melakukan perbandingan hasil penelitian yang telah dilakukan oleh beberapa peneliti sebelumnya.

\section{HASIL DAN PEMBAHASAN}

Tabel 1. Tabel sintesan studi literatur potensi daun ketepeng cina (Cassia alata L) terhadap jamur patogen pada manusia.

\begin{tabular}{|c|c|c|c|}
\hline $\begin{array}{l}\text { Nama jurnal/No. } \\
\text { Volume / Tahun / } \\
\text { Penulis }\end{array}$ & $\begin{array}{c}\text { Judul } \\
\text { Penelitian }\end{array}$ & $\begin{array}{c}\text { Desain } \\
\text { penelitian }\end{array}$ & Hasil penelitian \\
\hline $\begin{array}{l}\text { Jurnal sains dan } \\
\text { kesehatan Volume 1, } \\
\text { Nomor 6, 2016/ } \\
\text { Oktaviany Triana, } \\
\text { Fajar Prasetya, } \\
\text { Hadi Kuncoro, Laode } \\
\text { Rijai }\end{array}$ & $\begin{array}{l}\text { Aktivitas } \\
\text { antijamur } \\
\text { ekstrak daun } \\
\text { ketepeng cina } \\
\text { (Cassia alata } \\
\text { L) }\end{array}$ & $\begin{array}{l}\text { Eksperimen } \\
\text { laboratorik }\end{array}$ & $\begin{array}{l}\text { Ekstrak metanol, fraksi } \\
\text { n-heksana dan fraksi etil } \\
\text { asetat daun ketepeng } \\
\text { cina memiliki aktivitas } \\
\text { antijamur dalam } \\
\text { membunuh } \\
\text { pertumbuhan jamur } M \text {. } \\
\text { furfur. }\end{array}$ \\
\hline $\begin{array}{l}\text { J Agromeducine Unila } \\
\text { Volume } 5 \text { Nomor } 2 \\
\text { Desember 2018/ Tri } \\
\text { Umiana Sholehah, } \\
\text { Muhammad Ricky } \\
\text { Ramadhian, Efrida } \\
\text { Warganegara, Diana } \\
\text { Mayasari, Delvi } \\
\text { Rustaini Putri }\end{array}$ & $\begin{array}{l}\text { Perbandingan } \\
\text { efektivitas } \\
\text { terbinafin } \\
\text { dengan ekstrak } \\
\text { daun ketepeng } \\
\text { cina (Cassia } \\
\text { alata } L) \\
\text { terhadap } \\
\text { pertumbuhan } \\
\text { jamur }\end{array}$ & $\begin{array}{l}\text { Eksperimen } \\
\text { laboratorik }\end{array}$ & $\begin{array}{l}\text { 1. Ekstrak daun ketepeng } \\
\text { cina (Cassia alata. } L \text { ) } \\
\text { dengan konsentrasi } \\
20 \%, 40 \%, 60 \%, 80 \%, \\
100 \% \text { mampu } \\
\text { menghambat } \\
\text { pertumbuhan jamur } \\
\text { Malassezia furfur, } \\
\text { dengan nilai rerata } \\
20 \%(11,78 \mathrm{~mm}),\end{array}$ \\
\hline
\end{tabular}

Jurnal Medika: Media Ilmiah Analis Kesehatan Volume 5 Nomor 2, Desember 2020 ISSN: 2540-7910 2 


\begin{tabular}{|c|c|c|c|}
\hline & $\begin{array}{l}\text { (Malassezia } \\
\text { furfur) sebagai } \\
\text { etiologi } \\
\text { Pityriasis } \\
\text { versicolor }\end{array}$ & & $\begin{array}{l}40 \%(13,52 \mathrm{~mm}), \\
60 \%(15,44 \mathrm{~mm}), \\
80 \%(18,98 \mathrm{~mm}) \text { dan } \\
100 \%(25,46 \mathrm{~mm}) . \\
\text { Semakin tinggi } \\
\text { konsentrasi ekstrak } \\
\text { daun ketepeng cina } \\
\text { (Cassia alata. } L) \\
\text { maka semakin tinggi } \\
\text { zona hambat } \\
\text { pertumbuhan jamur } \\
\text { Malassezia furfur. } \\
\text { 2. Ekstrak daun ketepeng } \\
\text { cina (Cassia alata. L) } \\
\text { kurang efektif } \\
\text { dibandingkan dengan } \\
\text { terbinafin dalam } \\
\text { menghambat } \\
\text { pertumbuhan } \\
\text { Malassezia Furfur } \\
\text { sebagai etiologi } \\
\text { Pityriasis versicolor. }\end{array}$ \\
\hline $\begin{array}{l}\text { Internasional conference } \\
\text { ministry of health } \\
\text { polytechnic of kendari, } \\
\text { 2018/Anita Rosanty, } \\
\text { Reni Yunus }\end{array}$ & $\begin{array}{l}\text { Inhibition of } \\
\text { sabandara } \\
\text { leaves (Cassia } \\
\text { alata L) } \\
\text { against } \\
\text { Malassezia } \\
\text { furfur }\end{array}$ & $\begin{array}{l}\text { Ekperimen } \\
\text { laboratorik }\end{array}$ & $\begin{array}{l}\text { Based on the results of } \\
\text { the study, it can be } \\
\text { concluded that } \\
\text { sabandara laughter } \\
\text { extract is effective in } \\
\text { inhibiting Malassezia } \\
\text { furfur fungi. The biggest } \\
\text { concentration that can } \\
\text { inhibit the growth of } \\
\text { Malassezia fur fur is } \\
70 \% \text { with an } \\
\text { intermediate category of } \\
12.33 \%\end{array}$ \\
\hline $\begin{array}{l}\text { El-Qudwah, STAIN } \\
\text { Palangka Raya, 2012/ } \\
\text { Noor Hujjatusnaini }\end{array}$ & $\begin{array}{l}\text { Uji potensi } \\
\text { ektrak daun } \\
\text { ketepeng cina } \\
\text { (Cassia alata } \\
\text { L) terhadap } \\
\text { penghambatan } \\
\text { pertumbuhan } \\
\text { Trichophyton } \\
\text { sp }\end{array}$ & $\begin{array}{l}\text { Eksperimen } \\
\text { laboratorik }\end{array}$ & $\begin{array}{l}\text { 1. Perlakuan pemberian } \\
\text { konsentrasi ekstrak } \\
\text { daun ketepeng cina } \\
\text { (Cassia alata L) } \\
\text { mempunyai } \\
\text { pengaruh yang } \\
\text { sangat signifikan dan } \\
\text { zat anti microbial } \\
\text { yang terkandung di } \\
\text { dalamnya } \\
\text { mempunyai potensi } \\
\text { secara medis dalam } \\
\text { menghambat } \\
\text { pertumbuhan jamur } \\
\text { Trichophyton sp, }\end{array}$ \\
\hline
\end{tabular}

Jurnal Medika: Media Ilmiah Analis Kesehatan Volume 5 Nomor 2, Desember 2020 ISSN: 2540-7910 3 
yaitu pada umur

kultur 1 x 24 jam, 2 x

24 jam setelah

pemberian

perlakuan.

2. 2. Konsentrasi

ekstrak daun (Cassia

alata $\mathrm{L}$ ) yang efektif

dalam

penggunaannya

sebagai obat

penyakit kulit

sehingga dapat

menghambat

pertumbuhan jamur

Trichophyton $\mathrm{sp}$

adalah pada

konsentrasi $60 \%$.

Jurnal Photon, Volume

5, nomor 2, Mei 2015/

Zona Octarya, Robi

Saputra
Pengaruh jenis

pelarut

terhadap

jumlah ekstrak

dan daya

antifungi daun

ketepeng cina

(Cassia alata

L) terhadap

jamur

Trychophyton

$s p$

Pharmasipha Volume 2,

Nomor 1, Maret 2018/

Mathlail Fajri, Nurul

Marfu'ah, Lija Oktya

Artanti

Aktivitas antifungi daun ketepeng cina

(Cassia alata

L.) fraksi
Eksperimenla

boratorik

etanol, n-

heksan, dan

kloroform

terhadap jamur

Microsporium

canis

Ekperimen
Hasil uji aktivitas antifungi menunjukkan

ekstrak etanol daun

ketepeng memberikan

diameter zona

bening yang paling

besar dibandingkan

dengan ekstrak n-

heksana dan aquades

dengan ukuran diameter

zona bening

rata-rata $20,06 \mathrm{~mm}$.

Daun ketepeng cina

fraksi etanol, kloroform, dan n-heksan memiliki

aktivitas antifungi

terhadap jamur

Microsporum canis.

Fraksi yang paling

efektif dalam

menghambat jamur

Microsporum canis

adalah fraksi etanol,

pada konsentrasi $42,5 \%$.

Metabolit sekunder

yang terkandung dalam

fraksi etanol adalah

alkaloid, flavonoid, tanin, saponin dan terpenoid, sedangkan

pada fraksi kloroform

yaitu tanin, saponin, 
alkaloid, dan flavonoid, serta pada fraksi nheksan mengandung, alkaloid, saponin, tanin, dan terpenoid.

Jurnal penelitian farmasi

Indonesia Volume 5

Nomor 2, Maret 2017/

Nilda Lely, Dini Elinda, Lasmaryna Sirumapea
Aktivitas

antijamur

minyak atsiri

daun Ketepeng

cina (Senna

alata $L$ )

terhadap jamur

Oportunistik
Ekperimen

laboratorik

1. Minyak atsiri daun

ketepeng cina

memiliki

aktivitas antijamur

terhadap jamur

Aspergillus fumigatus,

Candida albicans dan

Penicillium

marneffei.

2. Secara deskriptif, pada konsentrasi terbesar dari pengujian minyak atsiri daun ketepeng cina terhadap jamur Aspergillus fumigatus, Candida albicans dan

Penicillium marneffei

Menunjukan aktifitas

antijamur kategori

kuat

yaitu berkisar 10-20

$\mathrm{mm}$.
Pada penelitian menggunakan studi literatur ini, penelitian menggunakan cara review dengan menemukan persamaan dan perbedaan dari 7 jurnal dan artikel penelitian literatur yang diteliti. Adapun yang menjadi pokok materi review yaitu metode penelitian yang digunakan dan hasil yang diperoleh dari masing-masing literatur. Penelitian ini berjudul studi literatur potensi antifungi daun ketepeng cina (Cassia alata L) terhadap jamur patogen pada manusia. Aktivitas antifungi merupakan kemampuan ekstrak atau perasan dalam membunuh maupun menghambat pertumbuhan jamur uji. Aktivitas antifungi ditunjukkan dengan adanya zona bening atau zona keruh yaitu daerah yang bening atau keruh dimana daerah tersebut tidak ditumbuhi oleh mikroba uji.

Pada penelitian yang dilakukan oleh Triana et al (2016) dan Sholehah et al
(2018) menunjukkan bahwa daun ketepeng cina berpotensi sebagai antifungi yang ditandai dengan terbentuknya zona bening pada media yang telah ditanami jamur uji. Selain itu pada penelitian yang dilakukan oleh Rosanty, dan Yunus (2018) dengan judul Inhibition of sabandara leaves (Cassia alata L) against Malassezia furfur menunjukkan hasil daun sabandara (Cassia alata L) berpotensi sebagai antiungi dengan menjukkan zona bening.

Selain itu penelitian menggunakan daun ketepeng cina dengan jamur uji yang berbeda seperti penelitian oleh Hujjatusnaini (2012), Octarya dan Saputra (2015) Fajri et al (2018) dan Lely et al (2017) menunjukkan daun ketepeng cina (Cassia alata L) berpotensi sebagai antifungi dengan terbentuknya zona hambat bening. Terbentuknya zona hambat ini dikarenakan daun ketepeng cina memiliki senyawa aktif berupa 
flavonoid, saponin, tannin dan antrakuinon yang berfungsi sebagai antiinflamasi, antialergi, antimikroba, antioksidan, dan efektif untuk beberapa golongan jamur. Senyawa ini bersifat antifungi karena dapat merusak membran sel, menghambat sintesis asam nukleat dan protein pada jamur. Selain bagian daun, dalam penelitian Abubacker (2008) bunga daun ketepeng cina juga menunjukkan berpotensi sebagai antifungi karena mampu menghambat pertumbuhan beberapa golongan jamur.

Menurut Fardiaz (1985) dalam Edo (2017), kemampuan zat antijamur menghambat pertumbuhan jamur dipengaruhi pula oleh beberapa faktor antara lain: konsentrasi zat antifungi, jenis, jumlah, umur, dan keadaan jamur, suhu, waktu kontak, sifat-sifat kimia dan fisik media pertumbuhan, seperti $\mathrm{pH}$, kadar air, nutrisi, serta jumlah komponen di dalamnya. Selain itu tingkat kerentanan jamur terhadap zat antifungi dipengaruhi oleh karakter dinding spora jamur dan kecepatan germinasi spora (Soltys 1963 dalam Edo 2017). Jenis pelarut yang digunakan dalam penelitian juga berpengaruh terhadap kandungan senyawa yang ada dalam sampel. Pelarut yang digunakan harus memiliki sifat kepolaritasan yang sama dengan senyawa yang akan ditarik (Sudarmadji, 1989 dalam Edo 2017).

Teknik perlakuan terhadap sampel dapat berupa ekstrak atau perasan. Ekstrak merupakan sediaan kering, kental atau cair yang dibuat dengan menyari simplisia nabati atau hewani menggunakan cara yang cocok (Ditjen POM, 1979). Ekstraksi adalah kegiatan penarikan kandungan kimia yang dapat larut sehinggga terpisah dari bahan yang tidak dapat larut dengan menggunakan pelarut cair. Sedangkan perasan merupakan cairan yang didapatkan dari hasil pemerasan. Penggunaan perasan lebih mudah dibuat daripada ekstrak karena hanya melalui proses pelumatan dan dan penambahan pelarut yang akan digunakan sehingga penggunaannya lebih mudah dan lebih cepat (Irsal, 2018).

Senyawa aktif dalam daun ketepeng cina (Cassia alata L) dapat diperoleh menggunakan teknik ektraksi atau perasan. Senyawa aktif ini bersifat antijamur. Akan tetapi senyawa aktif ini hanya bisa ditarik oleh pelarut yang sifatnya sama dengan sifat senyawanya seperti kepolarannya. Pada penelitian Nadziroh dan Eka (2018) tentang aktivitas antifungi air perasan Syzygium polyanthum terhadap Candida albicans. Pada penelitian ini pelarut yang digunakan adalah aquades dan menunjukkan bahwa air perasan daun salam tidak memiliki aktivitas antifungi dikarenakan tidak ada zona hambat karena kemungkinan senyawa antifungi seperti senyawa alkaloid, flavonoid, fenol, tanin, dan saponin yang terdapat dalam air perasan tidak bisa tersari atau terekstrak secara maksimal sehingga kadar senyawa dari air perasan menurun yang akan menyebabkan potensi dari senyawa pada air perasan tidak bisa maksimal untuk menghambat Candida albicans. Sedangkan pada penelitian yang dilakukan oleh Hammada et al (2018) dengan judul perbandingan efektifitas antara perasan daun seledri dan miconazole $2 \%$ terhadap Malassezia furfur menunjukkan hasil perasan daun seledri (Apium graveolens $L$.) menunjukkan aktivitas antijamur kuat yang mirip dengan 2\% miconazole dikarenakan senyawa aktif dapat larut dengan baik menggunakan pelarut yang sesuai. Pelarut yang digunakan yaitu DMSO 10\% yang bersifat polar dan larut dalam senyawa polar dan non polar. Dari penelitian ini menunjukkan bahwa teknik perasan dapat digunakan jika menggunakan pelarut yang sesuai dengan sifat senyawa aktif yang ingin ditarik selain itu pemilihan konsentrasi juga berpengaruh.

Berdasarkan hasil review studi literatur pada penelitian diatas bahwa perasan daun ketepeng cina (Cassia alata L) berpotensi sebagai antifungi karena memiliki senyawa aktif flavonoid, saponin, tannin, 
alkaloid dan antrakuinon yang efektif untuk beberapa golongan jamur.

\section{KESIMPULAN DAN SARAN}

Berdasarkan hasil studi literatur diperoleh kesimpulan bahwa daun ketepeng cina (Cassia alata L) berpotensi sebagai antifungi terhadap Malassezia furfur, Trichophyton sp, Microscoporium canis karena memilki senyawa senyawa aktif flavonoid, saponin, tannin, dan alkaloid.

Berdasarkan hasil studi literatur yang telah dilakukan, penulis menyarankan kepada peneliti selanjutnya untuk melakukan studi lapangan tentang potensi antifungi daun ketepeng cina (Cassia alata L) terhadap jamur patogen pada manusia atau menggunakan tanaman yang berbeda tetapi memilki senyawa aktif yang sama.

\section{DAFTAR PUSTAKA}

Anwar A.N. 2015. Manfaat Daun Ketepeng Cina (Cassia alata L) Sebagai Antifungi pada Tinea Pedis. J Agromed Unila, 4(2), 385388.

Amiruddin, M.D. 2003. Ilmu Penyakit Kulit. Lkis. Jogjakarta.

Brooks, Geo F, Butel, Janet S, Morse, Stephen A. 2013. Mikrobiologi Kedokteran Jilid 5. Salemba Medika. Jakarta.

Ditjen POM. 1979. Farmakope Indonesia, edisi III. Jakarta: Departemen Kesehatan RI. Halaman. 9, 755, 902.

Ditjen POM. 1986. Sediaun Galenik. Jakarta: Departemen Kesehatan RI. Halaman. 10-11.

Ditjen POM. 2000. Parameter Standar Umum Ekstrak Tumbuhan Obat.Cetakan Pertama. Jakarta: Departeman Kesehatan RI.

Edo T, Erina, Fakhrurrazi. 2017. Uji Daya Hambat Ekstrak Etanol Daun Ketepeng Cina (Cassia alata) terhadap Pertumbuhan Jamur Trichophyton sp. secara In Vitro. JIMVET. 01(1), 40-45.
Fajri M, Marfu'ah N, Artanti L.O. 2018. Aktivitas antifungi daun ketepeng cina (Cassia alata L.) fraksi etanol, n-heksan, dan kloroform terhadap jamur Microsporium canis. Pharmasipha 2(1), 6-8.

Gama M.P, Subakir, Suhardjono. 2011. Perbandingan Ekstrak Daun Ketepeng Cina (Cassia alata, linn) dengan Ketokenzol 2\% dalam Menghambat Pertumbuhan Malassezia furfur pada Pityriasis versicolor Secara Invitro. Skripsi tidak diterbitkan. Semarang: Program Pendidikan Sarjana Kedokteran Fakultas Kedokteran Universitas Diponogoro.

Hammada R, Pratiwi W, Fauzah S.N, Nauphar D, Amanah. 2018. Perbandingan efektivitas antara perasan daun seledri dan miconazole $2 \% \quad$ terhadap Malassezia furfur. Proceedings of International Conference on Applied Science and Health (3), 7377.

Hujjatusnaini N. 2008. Uji Ektrak Daun Ketepeng Cina (Cessia alata L) Terhadap Pengobatan Pertumbuhan Trichophyton sp. Skripsi tidak diterbitkan. Kalimantan: STAIN Palangka Raya.

Irsal M.N, 2018. Uji Potensi Antifungi Perasan Daun Urang Aring (Eclipta Prostrata) Terhadap Malassezia Furfur Yang Diisolasi Dari Penderita Pityriasis Versicolor (Panu). Karya tulis ilmiah tidak diterbitkan. Makassar: Akademi Analis Kesehatan Muhammadiyah.

Lay, B. 1994. Analisis Mikroba di Laboratorium. PT Raja Grafindo Persada. Jakarta.

Lely N, Elinda D, Sirumapea L. 2017. Aktivitas antijamur minyak atsiri daun Ketepeng cina (Senna alata L) terhadap jamur Oportunistik. 
Jurnal penelitian farmasi Indonesia 5 (2), 55-61.

Mar, N.F. 2011. Uji Efektivitas Antifungi Ekstrak Etanol Buah Cabai Rawit (Capsicum frutescens L) terhadap Pertumbuhan Jamur Penyebab Pitiriasis Versikolor secara In Vitro. Skripsi tidak diterbitkan. Makassar: Fakultas Ilmu Kesehatan. Universitas Islam Negeri Alauddin Makassar.

Nadziroh D.U, Setiawan N.C.E. 2018. Aktivitas antifungi perasan Syzygium polyanthum terhadap Candida albicans Journal Cis-Trans (JC-T), 2(2), 13-19.

Octarya Z, Saputra R. 2015. Pengaruh jenis pelarut terhadap jumlah ekstrak dan daya antifungi daun ketepeng cina (Cassia alata L) terhadap jamur Trychophyton sp. Jurnal Photon 5 (2), 15-21.

Partogi D. 2008. Pityriasis Versikolor dan Diagnosis Bandingnya. Erespiratory. Skripsi.Universitas Sumatera Utara. Medan.

Purwani H. 2013. Uji Efektivitas Ekstrak Daun Ketepeng Cina (Cassia alata L) Terhadap Pertumbuhan Jamur Malassezia furfur Penyebab

Santosa D, Gunawan D. 2005. Ramuan Tradisional untuk Penyakit Kulit. Jakarta: Swadaya.

Sholehah T.U, Ramadhian M.R, Warganegara E, Mayasari D, Putri D.V. 2016. Perbandingan efektivitas terbinafin dengan ekstrak daun ketepeng cina (Cassia alata L) terhadap pertumbuhan jamur (Malassezia furfur) sebagai etiologi Pityriasis versicolor. J Agromeducine Unila, 5 (2), 567-
Penyakit Panu. Karya Tulis Ilmiah. Lampung: Poliklinik Kesehatan Kementrian Kesehatan Tanjung Karang.

Putri, D.E, Mayasari, D, Warganegara, E, Ramadhian, M.R, Sholehah, T.U. 2018. Perbandingan Efektivitas Terbinafin dengan Ekstrak Daun Ketepeng Cina (Cassia alata. L) Terhadap Pertumbuhan Jamur (Malassezia furfur) Sebagai Etiologi Pi tyriasis Versicolor.

J Agromedicine Unila, 5 (2): 568.

Rukmana, W. 2017. Formulasi Dan Uji Stabilitas Fisik Sediaan Salep Antifungi Ekstrak Daun Ketepeng Cina (Cassia Alata L.). Skripsi tidak diterbitkan. Makassar: Fakultas Kedokteran Dan Ilmu Kesehatan Universitas Islam Negeri Alauddin Makassar.

Rosanty A, Yunus R. 2018. Inhibition of sabandara leaves (Cassia alata L) against Malassezia furfur. Internasional conference ministry of health polytechnic of kendar. 582591.

Santoso, H.B. 2019. Seri Mukjizat Daun Ketepeng Cina. Pohon cahaya semesta. Yogyakarta.

573.

Triana O, Prasetya F, Kuncoro H, Rijai L. 2016. Aktivitas antijamur ekstrakdaun ketepeng cina (Cassia alata L) I. Jurnal sains dan kesehatan, 1(6), 311-215.

Syamsuhidayat, S dan J. Ria. Inventarisasi Tanaman obat Indonesia. Jakarta: badan penelitian dan pengembangan Kesehatan. 